\title{
ISLAMIC HIGHER EDUCATION IN THE ASEAN REGION: OPPORTUNITIES AND CHALLENGES
}

\section{Frank Dhont}

University of Brunei Darussalam

Jl. Tungku Link, Gadong BE1410, Brunei

Email: frank.dhont@ubd.edu.bn

\begin{abstract}
This paper discusses the notion of Islamic Higher Education in ASEAN. It highlights the transformation of the ASEAN organization followed by the elaboration of Islamic Higher Education in the ASEAN Islamic Majority Nations of Brunei, Malaysia, and Indonesia. In these countries, some universities have emerged as exemplary institutions which are expected to uphold Islamic Higher Education. Opportunities and challenges of Islamic Higher Education among ASEAN countries are also discussed. Based on the investigation, it can be concluded that Islamic higher education has a proud tradition in Brunei, Indonesia and Malaysia and that now with the rising important of ASEAN there are ample opportunities for the development of IHE in ASEAN
\end{abstract}

Keywords: ASEAN, Challenges, Islamic Higher Education, Opportunities.

\begin{abstract}
ABSTRAK
Artikel ini membahas pemikiran-pemikiran tentang Perguruan Tinggi Islam di negara-negara ASE AN. Artikel juga menggarisbawabi transformasi organisasi ASE AN yang diikuti dengan perkembangan Perguruan Tinggi Islam di kawasan mayoritas Islam seperti Brunei, Malaysia, dan Indonesia. Di negara-negara ini, beberapa universitas telah berdiri sebagai model perguruan tinggi yang diharapkan bisa meningkatkan Perguruan Tinggi Islam. Artikel ini membahas pula beberapa kesempatan dan tantangan di Perguruan Tinggi Islam di negara-negara ASE AN. Berdasarkan hasil kajian, dapat disimpulkean babwa Perguruan Tinggi Islam di Brunei, Indonesia dan Malaysia memiliki kebanggaan atas tradisi mereka, dan Perguruan Tinggi Islam tersebut memiliki peluang untuk berkembang semakin besar seiring dengan perkembangan ASEAN.
\end{abstract}

Kata Kunci: ASEAN, Tantangan, Perguruan Tinggi Islam, Kesempatan 


\section{INTRODUCTION}

In the $21^{\text {st }}$ century, the Association of Southeast Asian Nations (ASEAN) is likely to grow into a political expression of identity for the member countries of Southeast Asia. Its presence and existence will be tested by time. To date, ASEAN comprises all countries in the region excluding Timor Leste. Those member countries joined the organization, and they represent very diverse nations.

Politically speaking, these countries are not concerned with the notion of unity when they joined the organization. It was the notion of mutual respect that brought them together in ASEAN with the emphasis on the maintenance of distinct political borders. This commitment is embodied in the motto of ASEAN: "One Vision, One Identity, One Community" which is shown on its official website ("Asean motto," n.d.).

Historically speaking, the organization, in fact, came into existence since 1967 when Indonesia along with Malaysia, the Philippines, Thailand, and Singapore joined forces and established it. Brunei affiliated itself in 1984 and followed later. In the 1990s Vietnam, Laos, Cambodia, and Myanmar also integrated and became part of the organization. Other promising candidates for membership include Papua New Guinea and Timor Leste. They are currently observer states and especially Timor Leste is making steps that will eventually lead to full membership.

Timor Leste has spent time in its effort to join the ASEAN organization. It has been working to establish diplomatic links with Brunei Darussalam since 2014 ("Asean," n.d.). In line with this, Brunei also did the same in the state of Timor Leste ("Asean," n.d.). This is just one example of the diplomacy preceding entry into the ASEAN group. It, therefore, seems only a matter of time before Timor Leste will officially integrate into ASEAN and join the real Southeast Asian member countries (POCS, 2012).

ASEAN is expected to help and support its' members in facing the chance and the challenge in global era. Higher education matter is one of the problem. Every country in ASEAN should be able to face globalization era which change rapidly. In this paper, it would be explored about the recent development in ASEAN organization, minority and majority Muslim country in ASEAN, the chance and challenge in Islamic higher education in ASEAN through the literature review.

\section{DISCUSION}

\section{Cooperation Redefined}

In the beginning of this millennium the cooperation among ASEAN member countries was lifted to a whole new level. This was marked by the ASEAN Charter of 2008 which has brought formal agreement with various 
implications for the signatory member states. These states agreed to cooperate more closely and to build various cooperations in many aspects including: political, legal and institutional bodies (Anindhitya, n.d.).

The ASEAN charter 2008 had a major impact. One element is that the member countries should create more options for cooperation which are tangible in nature to ordinary people. To exemplify, the member countries are committed to remove the tourist visa requirement for traveling in the ASEAN region. This decision was signed on 25 July 2006 (Johan, 2016). This program has resulted many advantages. Removing visa requirement makes it easier for people from Southeast Asia to travel in the various countries of the region and boosts tourism development in member countries. In the past 10 years since the signing of the agreement, the number of tourists and other linkages has increased as this market of 625 million people kept growing in importance. In this community of 625 million people one country represents a sizable piece of this 'opportunity' pie. Among the member countries of ASEAN, Indonesia has the largest population consisting of 255 million people.

\section{Islamic Majority Nations in ASEAN}

With regard to Islamic religion adherence among ASEAN member countries, the nations that adhere to Islam are in fact quite limited. There are three countries specifically which have a Muslim population majority residing in thei region: Indonesia, Malaysia and Brunei. These Muslim-dominated nations have the implementation of the Shafi'i school of Sunni jurisprudence in common. Among the three nations, Brunei has the highest level of allegiance to the Shafi'i school of thought as it was formally encoded in the Bruneian constitution. The influence of the Shafi'i school of thought is strong and it is used in many regions with sea lanes which helped it spread across Southeast Asia and elsewhere. In other words, its strength and influence can be found all around the Indian Ocean from Somalia to Sumatra.

\section{Islamic Minority Nations in ASEAN}

Unlike Islam in Malaysia, Indonesia and Brunei, Islam in the remaining countries of ASEAN is the religion of a minority of the population. Islam with a small number of adherents can be found in the following nations: Myanmar, Singapore, the Philippines and Thailand. This situation can be traced back historically. The spread of Islam all over the Southeast Asian nations is dicussed in history books. It is also part of ASEAN heritage that many sultanates sprouted up all over this area and played a significant role in spreading Islam. These old kingdoms with their Islamic traditions formed the root for the existing Islamic communities in the region today. 
In addition to the countries mentioned above, history has recorded that Islam also took root in other countries of the region including East Timor, Vietnam, Myanmar and Laos. In East Timor, there exist small numbers of Muslims today (POCS, 2011). In South Vietnam, Champa once was a strong power that had embraced Islam. Likewise the Rohingya in Myanmar form another Islamic people and all these are part of that diverse community of Southeast Asia. People who descended from the Cham minority are still present today in Cambodia and Vietnam. Even today in Phnom Penh one can hear the call to prayer and in Ho Chi Minh City there are several mosques that are being visited frequently by many Muslims. The only country where very few Muslims live today seems to be Laos.

\section{The ASEAN Motto and its Contemporary Hot Issues}

ASEAN is increasingly being more and more an organizationalpolitical reality and it is warranted to take a closer look at how this fits the ASEAN motto: "One Vision, One Identity, One Community". The motto is subject to many interpretations if ASEAN is seen from its rich diversity. In the same vein, it is worth quoting at length what the former SecretaryGeneral of ASEAN, Dr. Surin Pitsuwan, stated in a lecture at the University of Brunei Darussalam when in January 2016 he delivered his personal insights as a key figure in Asia concerning the importance of ASEAN and connectivity:

"I think the word connectivity means more than just physical infrastructure. I think connectivity with a global scene, mindset, regional processes of change, of integration, of evolution - all these things need to be communicated to the younger generation everywhere."

"It is imperative to look at the potential, the opportunities and the challenges that the ASEAN platform provides for an "integrated, contemporary role" of the unique cultures for the region and the world. It is a big question, but I think it is the right question," "Next year is our 50th anniversary, but we have a long way to go into the future, and we have to manage our diversity."

Referring to the speech delivered by Dr Surin Putsiwan, the term 'diversity' has several interpretations. In this context, he saw diversity as prevalent in all aspects: governance, socio-cultural aspects and the economy. Just as the ASEAN community is built on these three pillars of cooperation: Political-Security, Economic, and Socio-cultural (Pitsuwan, 2016). 


\section{ASEAN's Three Pillars}

Dr Surin Putsiwan went on to explain that the socio-cultural pillar is paramount to strengthen the ASEAN Community. This consists of unifying a joint ASEAN identity with a sense of membership in a single ASEAN community. "If socio-cultural is not solid, the other two pillars cannot make it," (Pitsuwan, 2016).

ASEAN's "One Vision, One Identity, One Community" in the complete diversity of ASEAN is not that easy to achieve. The mosaic of ASEAN as one simply because of the diversity that comes naturally to the region is an issue most scholars of Southeast Asia see as a challenge. Yet the reality of ASEAN cannot be ignored. ASEAN despite not being political in nature in the sense that it would interfere in member states, seems very political as it has an organizational-political vision that is clearly there, selfdefining and being implemented through intergovernmental cooperation.

The one community can, to an extent, be created by artificially drawing borders around the countries of ASEAN or Southeast Asia but this leaves much to be desired as for matters such as 'feeling' Southeast Asian. This one identity as Southeast Asian or ASEAN citizen seems to be based on fostering a feeling of a togetherness of people from the region in this ASEAN zone. As I recall the words of the Secretary-General in the lecture: "ASEAN does not ask one to give up his/her identity but simply to add another layer as ASEAN person”.

\section{ASEAN and Future Member Countries}

The idealistic concept of ASEAN is not impossible to achieve but the degree to which it will be implemented and internalized by the population of the different member nations of ASEAN is of course the major question. Too many variables play a role and this makes such a prediction very hard. ASEAN emphasizes youth and future. An ASEAN identity without Timor Leste seems to create an odd artificial distinction between the concepts of 'Southeast Asia' and 'ASEAN' that will however most likely resolve itself with membership but has not yet at this stage. It would greatly help ASEAN if this happened as it would formalize ASEAN as the political expression of Southeast Asia as a political entity.

In fact, the ASEAN concept plus three where Korea, Japan and China seem interested in ASEAN is also a very complicated format that may very well be short lived as there seems no historical or political Southeast Asian 'identity' behind it. In the past Southeast Asia has always been to an extent identified by what it was not. Southeast Asia was halfway between India and China. Wedged between South Asia and East Asia, this group of very diverse nations formed Southeast Asia and in that space ASEAN grew today. Islam 
formed a large part of that joint identity yet represents only one of the layers of the cake or only one group of similar stones in the whole mosaic of ASEAN. Despite Islam not being prevalent to the same degree in all parts of the region, it still maintains enough linkage potential to fully take advantage of this future mobility that the new ASEAN policies promise.

\section{ASEAN and Islamic Higher Education}

In this complex constellation of political identity and issues aimed at the future and youth of ASEAN, Islamic education, and its development is but one of the networks that were originally part of this complex Southeast Asia. These networks, despite being themselves wider in scope than Southeast Asia itself, do form an element of uniqueness in Southeast Asian identity and have never really ceased to exist over the centuries.

Colonialism, Nationalism, and the modern nation-states all ended up doing little to stop the contacts between Muslims in Southeast Asia and beyond. Whenever attempts were made, Islam proved too resilient to be bottled up inside of the individual nation-state and by doing so it typified that Southeast Asian identity concept of diversity is yet somehow creating unity.

ASEAN is more and more becoming an organizational-political reality and also the mobility of people, news through internet access and individual travel are also more and more part of reality today. Considering this context and the introduction above, the issue which occurs concerning Islamic education is clear. Will ASEAN offer opportunities to Muslims and Islamic higher education (IHE)? or will ASEAN present a challenge to IHE?

One of the aspects that most countries are concerned about is education. ASEAN and its member countries are committed to work on producing results on this aspect. In this paper the cooperation in regards to Islamic education will be analyzed in those ASEAN member countries where the Muslim population forms the majority. Brunei, Malaysia and Indonesia all represent a population consisting of a majority of Muslims in each respective country. These countries also in common that they work toward developing Islamic higher education and ASEAN clearly impacts higher education through the potential of cooperation it brings to Southeast Asia.

IHE is rooted in tradition, national heritage and has popular support as many students are enrolled in the institutions of IHE. IHE can be traced back to a historical tradition of education in some ASEAN countries. IHE has therefore proven itself and became part of the national heritage that became a source of pride for that particular country. This created a situation where today IHE has since long been an influential part of the national heritage of a country like Indonesia, Malaysia and Brunei. Also, IHE also gained public support from the society in these particular countries where it 
is seen as very crucial in developing and contributing positively to the country's human development.

There are many major factors, which have supported IHE to be able to become a successful international model. One of the greatest factors is a linguistic similarity. The linguistic similarity is shared among the Malay countries of Malaysia, Indonesia and Brunei. This has assisted IHE in disseminating knowledge and science for youths for many decades. In those countries, IHE has contributed significantly to their human development. The shared Malay language is one of the greatest assisting cultural tools that support Islamic education in those countries.

Brunei, Malaysia, and Indonesia represent Muslim majority nations that have historically developed IHE in their respective countries as part of their national heritage and cultural identity. It is widely known that there are opportunities for Islamic universities in Indonesia, Malaysia, and Brunei to work together because of these past achievements nationally. In trying to make use of their expertise in IHE, these countries can teach students more than only the text of the Holy Quran. Their expertise and efforts provided many lessons which can now be learned and transmitted to future generations of students.

Possible cooperation of these three ASEAN countries in their close interaction on IHE will produce new research and more knowledge. This cooperation will no doubt produce many advantages for IHE institutions in these respective countries. The interaction will boost and strengthen Islamic universities' vision and mission regarding their knowledge development and research efforts. These promising advantages can be achieved by the three countries if they collaborate on agreed objectives and goals. The number of exchanges of students and lecturers between the different institutions is already quite numerous as the Malay language facilitates this uniquely well.

In the following section, this paper is going to elaborate on Islamic Higher Education (IHE) in each country separately. Malaysia, Brunei, and Indonesia will each $\mathrm{c}$ be featured each with their own example of Islamic Higher education based on a representative university for that country.

\section{Brunei's IHE}

In Brunei Darussalam, the Sultan Omar Ali Saifuddien, Centre for Islamic Studies, claims itself to be one of the youngest members of the University Brunei Darussalam academic community (Saifuddien, n.d.). We can read how it sees itself:

"It takes pride in being born with a praiseworthy mission to thrive as one of the world's leading graduate centers for the study of Islam and contemporary issues. Its historical establishment was announced by 
His Highness the Sultan and Yang Di-Pertuan of Negara Brunei Darussalam, Sultan Hassanal Bolkiah Mu'izzuddin Waddaulah in his royal speech (titah) on $30^{\text {th }}$ September 2010 at the UBD's $22^{\text {nd }}$ Convocation. SOASCIS is now a steadily growing graduate center with an international image and outlook that has the appeal of attracting students from many parts of the world to pursue Master's and Doctoral studies on various aspects of Islam and contemporary issues. The Centre is also attracting academics from various Muslim and nonMuslim countries to join either its academic staff or its pool of researchers employed under the various schemes of Visiting Fellowships that it is offering." (Saifuddien, n.d.).

Some Indonesian scholars are lecturers as well as students in the University of Brunei Darussalam. Brunei goes even further in Islamic learning and has even founded in 2007 specific university for Islamic learning. Universiti Islam Sultan Sharif Ali offers a whole range of programs related to Islamic learning (Saifuddien, n.d.). In its official website the mission of the university is displayed as follows:

"Universiti Islam Sultan Sharif Ali - better known as UNISSA - is a "pure Islamic University" of international standard that offers a variety of programs across disciplines based on Al-Quran and al-Sunnah. Established in 2007, it attests to the commitment of His Majesty the Sultan and Yang Di-Pertuan of Brunei Darussalam in upholding Islam through education, in this blessed land of Brunei Darussalam and towards the development of the ummah in general. As the second state university, UNISSA strives to produce Muslim scholars and intellectuals who contribute to the development of the ummah and the state, in support of the efforts of Brunei Darussalam towards becoming a dhikir nation with continuous blessings from Allah." (Saifuddien, n.d.).

\section{Malaysia's IHE}

The second country with regard to IHE institutions to be discussed in this section is Malaysia. Malaysia is also committed toward achievement on the human development index especially in upholding and further promoting quality education. Consistent with this national mission, Malaysia maintains several universities which have been top destinations for international students including Bruneians and Indonesians to further their studies pursuing doctoral degrees in local Malaysian Islamic Universities. Among top universities, the International Islamic University of Malaysia is worth discussing as example of IHE in Malaysia. 
The International Islamic University Malaysia has its core in Selangor, Malaysia. In Petaling Jaya and Pahang are its Centre for Foundation Studies and the medical branch. IIUM is sponsored by eight countries from the Organization of Islamic Cooperation (OIC) and the university was established in May 1983.

The University was founded on Islamic principles by what was then the Organization of the Islamic Conference. The Islamic values permeate into all disciplines, and the quest for knowledge is in the IIUM philosophy considered to be "an act of worship" ("Philosophy," n.d.).

IIUM currently offers undergraduate and graduate degrees up to the Ph.D. level. There are 14 kulliyyah (college or faculty in Arabic). Two prominent faculties are the Ahmad Ibrahim Kulliyyah of Laws and the Kulliyyah of Islamic Revealed Knowledge and Human Sciences. Many other programs related to economic and management and the exact sciences such as for instance various medical and technological disciplines are also offered.

Given the short description of IIUM as an example of a Malaysian Institute of IHE, it is clear that Malaysia has shown a major commitment to Islamic higher education. In addition, Malaysia has also spread its wings and engaged in collaboration on IHE with neighboring countries. The country has already made its links with places like Vietnam to train Islamic religious teachers. The country has tried to play an important role regarding IHE in the ASEAN region.

\section{Indonesia's IHE}

Indonesia is one of the leading countries in ASEAN that also has a historical record and expertise in Islamic higher education. Going back to the foundation of Pesantren and Madrasah Indonesia has a long history of IHE. Recently the democratization process in Indonesia has contributed significantly in developing Islamic education (Haryanti \& Firdaus, 2016). Haryanti of the State Islamic University of Sunan Gunung Djati (Universitas Islam Negeri/UIN SGD Bandung) writes that from the 1980s Indonesian Islamic education institutions such as Madrasab amalgamated the Indonesian national curriculum and Islamic education (Haryanti \& Firdaus, 2016).

In Indonesia, the Minister of Religious Affairs is responsible for developing IHE in Indonesia. Indonesia possesses a myriad of IHE institutions either private of state controlled and there are many changes that occurred in Indonesia's IHE state institutions (Lukens Bull, 2016)

Ronald Lukens-Bull concluded that the Indonesian State Islamic Higher Education (Perguruan Tinggi Agama Islam Negeri/PTAIN) system came into being with as goal a progressive apolitical form of Islam and that by this very nature PTAIN faculty members have the potential to influence the 
Indonesian Islamic community in their capacity of functionaries in the official state format of IHE in Indonesia (Lukens Bull, 2016). These institutions have shaped the Indonesian Islamic community and represent Indonesian Islamic expertise through their research.

PTAIN system has tried to function to the best of its capacity for the students learning in these institutions of IHE. There is great progress in its development to serve the students but PTAIN still has many challenges to overcome. A study in the UIN SGD Bandung examined the university management processes and activities from the viewpoint of implementation of knowledge management (Sulastri \& Mohammed, 2016). The study found deficiencies that need to be addressed further as various knowledge management tools were not yet optimized but progress was clearly made in the implementation of knowledge transmission processes in UIN SGD Bandung (Sulastri \& Mohammed, 2016).

The cases mentioned above of IHE in Brunei, Malaysia and Indonesia clearly show the achievements and deep commitment and engagement of these ASEAN countries with Islamic higher education as part of their identity. With ASEAN these many decades of expertise building can be more easily infused into a wider network of institutions of IHE. The way this blending of knowledge will play out in the various institutions of IHE in ASEAN nations will depend on the degree to which each country's local focus and achievements in IHE are absorbed by the other ASEAN nations and their institutions of IHE.

\section{Opportunities for IHE among ASEAN Countries}

The development of Islamic education in ASEAN clearly holds several opportunities. These possible opportunities include exchange between the various countries of ASEAN to develop Islamic education and allow a deeper understanding and greater spread of Islamic education in the region of ASEAN.

We already see interest by potential students of Islam in the Muslim minority countries of ASEAN who are interested in tapping into the expertise that was built up by Indonesia, Brunei and Malaysia on IHE. In April 2015 the ambassador from Timor Leste visited UNISSA in Brunei to explore the opportunity of student exchanges between Brunei and Timor Leste for citizens who would like to learn Arabic as "with two percent of its population being Muslims who mostly speak Indonesian Malay" (Saifuddien, n.d.). This clearly illustrates again that this access to Malay as lingua franca of the region helps facilitate enormously the exchange of students in the region. As Timor Leste attempts to enter ASEAN these exchanges could bring the nation closer to those countries who would offer Islamic education. How 
these relations will develop seems to an extent somewhat political as all three Muslim countries of ASEAN and their Islamic education centers basically compete for the same pool of students.

Indonesian Islamic Universities should continue to build links with various institutions and universities abroad in the whole of ASEAN because of the strength of Indonesia as major player in ASEAN and the Muslim world. The risk that students will see these very specialized institutions as limiting and not preparing people adequately for future professional life is also a challenge that has to overcome through internationalization and modernization based on the expanding knowledge-experience base of institutions of IHE. Therefore, it is important that through education and exchange in ASEAN as well as a broader development incorporating Islam and Islamic values in teaching, these universities also maintain competitive research and teaching profiles that prepare students for broader secular career choices. The youth is the future of ASEAN and it seems therefore only natural that Islamic higher education continues to implement better procedures in order to offer the very best in IHE for this ASEAN youth to be well equipped to the challenges of ASEAN in the $21^{\text {st }}$ Century.

\section{Challenges for IHE among ASEAN Countries}

One major issue with this whole process is of course that as ASEAN is working toward an ASEAN identity and because ASEAN also holds many non-Muslim members, the emphasis on Islamic education could be seen as dividing instead of unifying. The 'vision' of senior administrators in ASEAN seems to be that these is room for diversity and Islam is a major element in ASEAN as it has been historically but it is understood to be only part of the multi-facetted identity. However, there is also a more basic challenge that presents itself to the proponents of Islamic education. The education model here is that the knowledge drawn from the sacred Muslim text is spread and shared in the community to become accessible for all especially in an ASEAN context that by nature is so multi-facetted yet home to many Muslims. This in itself is already a challenge but it brings out a more fundamental second challenge. Islamic higher education can enrich ASEAN and there is a desire by various countries to learn from what can be provided.

Brunei, Indonesia and Malaysia are largely in competition here as they each have accomplished a lot in the field of IHE. Each of these countries has strong points and weak points to compete to provide education opportunities to the Islamic segment of the population of ASEAN. Although from the examples mentioned above Brunei is clearly trying to build itself as an Islamic society, the appeal of the country is somewhat limited if compared to the much larger neighbor Indonesia. Cooperation with the other nations through 
exchange would be an ideal solution but the modalities of this cooperation would be something that in the future will become clearer. Islam is an identity marker of these three countries and the attempts to have other Southeast Asian Muslims come to these centers of learning is a quite complicated matter based on the national accent of IHE in each of these three nations.

Because of the increasing proximity of other people in ASEAN, opportunities for exchange are plentiful. Some links have been forged through years of exchange predating ASEAN. Most Cham related people in Ho Chi Minh City for instance had received their Islamic training in Kelantan, Malaysia and because of this spoke Malay (Dhont, 2015). Islamic Universities all over Southeast Asia should take advantage of these in the spirit of ASEAN and especially to counter a more negative result of increased mobility in the region. The ease of exchange in ASEAN has of course also caused networks of underground radical teaching to more easily abuse these facilities. The Muslim area in the Southern Philippines seems a case in point where networks have grown that spread beyond the local nation to the wider region. Even in Malaysia and Indonesia radical thought might and can also spread. It will therefore be even more important for voices from more erudite Muslim scholars and institutions of Islamic higher education to cooperation across national borders in order to guide Muslim students of ASEAN nations.

\section{CONCLUSION}

In conclusion it seems clear that Islamic higher education has a proud tradition in Brunei, Indonesia and Malaysia and that now with the rising important of ASEAN there are ample opportunities for the development of IHE in ASEAN. The Malay language acts as a great facilitator for exchange. The fact that these three ASEAN countries have Islamic religion in common as an important element of their own identity as well as many people in ASEAN indicates that the increased cooperation of ASEAN countries will enrich and add to the knowledge base of IHE through the increasing interaction on an international ASEAN framework level where national boundaries will become less obstructive to the spread of IHE knowledge. It is clear that in order to prevent radicalism to take root through the ASEAN network the more scholarly voices of Islamic institutions of Islamic higher education will be essential as they cooperate in ASEAN. To what extent the various strands of IHE (Bruneian, Malaysian and Indonesian) will blend and interact remains a process that will require further study as ASEAN facilitated interaction between institutions and students of IHE will continue to develop in the future. This new era of exchange in ASEAN offers many 
opportunities for IHE universities in the three Muslim majority countries of ASEAN in the spreading of Islamic higher education expertise and in linking academically with other Islamic communities in ASEAN in order to deepen and develop Islamic education as part of the ASEAN vision of a Southeast Asian identity. The extent to which all this will be realized depends on the use the institutes of Islamic education will make of the opportunities of exchange and growth offered by ASEAN and future scholarship will be essential to gauge the success of these processes of ASEAN identity formation.

\section{BIBLIOGRAPHY}

Anindhitya. (2007). Asean charter. Retrieved from http://asean.org/asean/asean-charter/.

Asean. (2007). Retrieved from http://asean.org/.

Asean motto. (n.d.). Retrieved from http://asean.org/asean/aboutasean/asean-motto/.

Dhont, F. (2015). Personal visit. Ho Chi Minh City.

Haryanti, E., \& Firdaus, F. (2016). Contribution of indonesian democratic to islamic education. Jurnal Pendidikan Islam, 1(2), 165-182.

Johan. (2016, July 25). Asean framework agreement on visa exemption. Retrieved from http://asean.org/?static_post=asean-frameworkagreement-on-visa-exemption-kuala-lumpur-25-july-2006-2.

Lukens Bull, R. (2016). The political use of islamic variation in indonesian islamic higher education. Jurnal Pendidikan Islam, 2(2), 193. https://doi.org/10.15575/jpi.v2i2.786.

Philosophy. (n.d.). Retrieved from http://www.iium.edu.my/aboutiium/philosophy.

Pitsuwan, S. (2016, Januari). Universiti Brunei Darussalam. Retrieved from http://www.ubd.edu.bn/news-and-events/highlightsarchive/2016/january/former-secretary-general-of-asean-dr-surinpitsuwan-is-ubd-distinguished-professor/.

POCS. (2011). Timor Leste. Retrieved from http://asean.org/timor-leste-tostrengthen-cooperation-with-asean/.

POCS. (2012, October 4). Cooperation. Retrieved from http://asean.org/timor-leste-continues-to-pursue-cooperation-withasean/.

Saifuddien, O. A. (n.d.). Soascis. Retrieved from http://www.unissa.edu.bn/. 
Frank Dhont

Sulastri, L., \& Mohammed, H. A. H. A. (2016). Knowledge management in islamic higher education (a case study on implementation of knowledge management tools in uin sgd bandung). Jurnal Pendidikan Islam, 2(1), 3053. 